\title{
Acute Respiratory Distress Syndrome
}

Editors

MICHAEL A. MATTHAY

KATHLEEN D. LIU

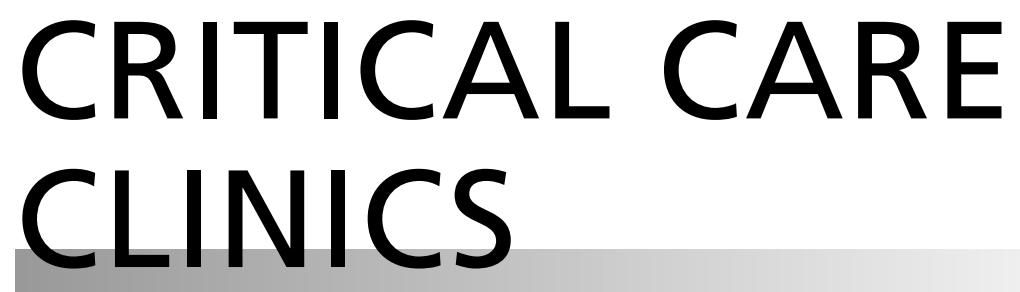

www.criticalcare.theclinics.com

Consulting Editor

GREGORY S. MARTIN

October 2021 • Volume 37 • Number 4 